\title{
Obesity, essential hypertension and renin-angiotensin system
}

\author{
Julian Segura* and Luis M Ruilope \\ 'Hypertension Unit, Hospital 12 de Octubre, Av. Córdoba s/n, 28041 Madrid, Spain
}

Submitted 1 September 2006: Accepted 2 March 2007

\begin{abstract}
Abdominal obesity is a risk factor for cardiovascular disease worldwide, and it is becoming a dramatic issue for national health systems. Overweight and obesity are highly associated with multiple comorbidities, elevated blood pressure values, dyslipidaemia, reduced insulin sensitivity and alterations of large and minor vessels.

Activation of the renin-angiotensin system (RAS) in adipose tissue may represent an important link between obesity and hypertension. Angiotensin II has been shown to play a role in adipocyte growth and differentiation. Adipocytes also secrete adiponectin, enhancing insulin sensitivity and preventing atherosclerosis. Blockade of the RAS with either an angiotensin-converting enzyme inhibitor or an angiotensin II receptor blocker results in a substantial increase in adiponectin levels and improved insulin sensitivity. Obesity-related hypertension needs a comprehensive approach to treatment including both weight loss and pharmacological therapies. Antihypertensive drugs prescription should be based on guidelines recommendations for management of hypertension, taking into account the growing evidences about the relationship between some antihypertensive drugs and the development of new-onset diabetes.

This review discusses the role of RAS in the relationship between obesity, essential hypertension and insulin resistance.
\end{abstract}

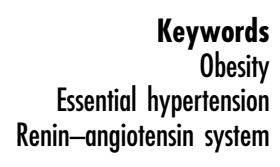

eywords

Obesity

Renin-angiotensin system
Abdominal obesity is characterised by the accumulation of visceral adipose tissue, and it is a major risk factor for the development of hypertension ${ }^{1,2}$. Abdominal obesity is also the principal risk factor for insulin resistance and the development of type 2 diabetes $^{3}$. Hypertension in obese individuals is commonly complicated by the concomitant presence of dyslipidaemia, hyperinsulinaemia, impaired glucose tolerance and other components of the metabolic syndrome ${ }^{4}$. Sodium retention, volume expansion and increased cardiac output are common findings in obese individuals. These changes are largely attributable to increased activity of the sympathetic nervous system and insufficient suppression of the renin-angiotensin system (RAS). Recent data show increased expression of angiotensin II-forming enzymes in adipose tissue, and increased activity of the RAS has recently been implicated in the development of insulin resistance and type 2 diabetes $^{5}$. These evidences could explain the relevance of obesity as an important predictor of overall cardiovascular morbidity and mortality ${ }^{1,2}$.

This review discusses the role of RAS in the relationship between obesity, essential hypertension and insulin resistance.

\section{Renin-angiotensin-aldosterone system and obesity-related hypertension}

Although excess weight gain is associated with marked sodium retention and expansion of extracellular fluid volume, obese subjects usually have increases in plasma renin activity, plasma angiotensinogen (AGT), angiotensin-converting enzyme (ACE) activity and plasma angiotensin (Ang) II levels ${ }^{6}$. Figure 1 summarises the mechanisms by which obesity increases renal tubular sodium reabsorption, impairs pressure natriuresis and causes hypertension as well as progressive glomerular injury ${ }^{6}$. A significant role for Ang II in stimulating sodium reabsorption, impairing renal-pressure natriuresis and causing hypertension in obesity is supported by the finding that treatment of obese dogs with an Ang II antagonist or ACE inhibitor blunts sodium retention and volume expansion, as well as elevated arterial pressure ${ }^{7,8}$. Also, ACE inhibitors are effective in reducing blood pressure in obese humans, particularly in young patients?

Activation of the RAS in adipose tissue may represent an important link between obesity and hypertension ${ }^{10}$. Adipose tissue is an important production site of $\mathrm{AGT}^{11}$, 


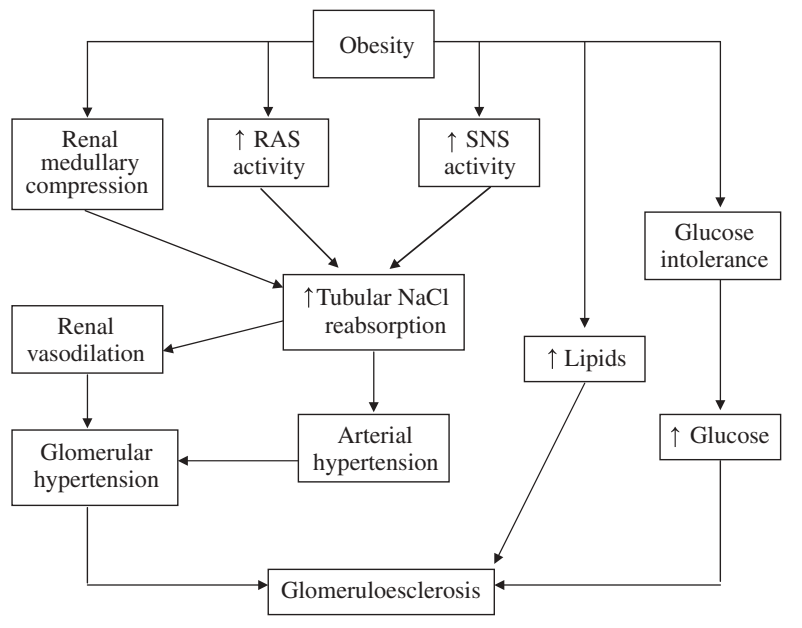

Fig. 1 Mechanisms involved in development of obesity-related hypertension and subsequent renal damage (modified from Hall ${ }^{6}$ )

and several studies have reported correlations between plasma AGT concentrations, blood pressure and body mass index ${ }^{12,13}$. Overexpression of AGT exclusively in adipose tissue in AGT knockout mice not only resulted in measurable plasma levels of AGT but also resulted in an increase in blood pressure, restoration of sodium balance and augmented adipocyte size $^{14}$, whereas RAS suppression by either an ACE inhibitor or deletion of the type-2 angiotensin-II receptor leads to a decrease of adipocyte size $^{15,16}$. Ang II has also been shown to play a role in adipocyte growth and differentiation ${ }^{17}$. Furthermore, locally produced Ang II may directly stimulate leptin release from adipocytes, an effect that may be counterbalanced by increased sympathetic activity ${ }^{18}$. Adipocytes also secrete adiponectin, a plasma protein that is downregulated in obese individuals ${ }^{19}$. Adiponectin enhances insulin sensitivity and prevents atherosclerosis ${ }^{20}$. Recently, it has been shown that blockade of the RAS with either an ACE inhibitor or an Ang II receptor blocker results in a substantial increase in adiponectin levels associated with an increase in insulin sensitivity ${ }^{21}$. Further support for the involvement of RAS activation in obesityassociated hypertension came from a dietary intervention study in menopausal women. Engeli et al. ${ }^{22}$ showed that $5 \%$ weight loss resulted in a $7 \mathrm{mmHg}$ reduction of ambulatory blood pressure and that the decrease was accompanied by significant declines of serum AGT (27\%), renin (43\%) and ACE activity (12\%) as well as AGT expression in adipose tissue (20\%).

Aldosterone has been implicated in the development of hypertension associated with obesity ${ }^{23}$. Plasma aldosterone levels are elevated in obese hypertensives, especially in those with visceral obesity ${ }^{24}$. The mechanisms by which excess fat could increase aldosterone are unknown, but it may relate to the production by adipocytes of potent mineralocorticoid releasing factors ${ }^{25}$ or to the ability of oxidised derivatives of linoleic acid to induce aldosterone synthesis ${ }^{26}$. The involvement of aldosterone in obesity-associated hypertension has been demonstrated by the blockade of mineralocorticoid receptors with the specific antagonist eplerenone in highfat-fed $\operatorname{dogs}^{27}$.

\section{Insulin resistance and obesity-related hypertension}

Resistance to insulin-mediated glucose uptake by the skeletal muscle, which is often linked with abdominal obesity, greatly increases the likelihood of developing abnormalities such as type 2 diabetes, hypertension and dyslipidaemia ${ }^{28}$. The cluster of these independent cardiovascular risk factors is known as metabolic syndrome, described by the NCEP ATP III ${ }^{29}$, and it is well-recognised that hypertensive patients presenting metabolic syndrome show an increased cardiac, renal and vascular damage $^{30-32}$. In the general US population, the ageadjusted prevalence is $24.0 \%$ for men and $23.4 \%$ women $^{33}$, and it rises continuously in an epidemic progression $^{34,35}$. Among hypertensive patients attended to in our hospital-based hypertension unit, the overall prevalence of metabolic syndrome rise to $49.4 \%$, with no difference between genders ( $47.8 \%$ in men and $50.5 \%$ in women $)^{36}$. Finally, in a population-based cohort of type 2 diabetes, a prevalence of metabolic syndrome of $75.6 \%$ has been recently described ${ }^{37}$. The International Diabetes Federation has recently described a new definition of metabolic syndrome, with more strict criteria for waist circumference ( $\geq 94 \mathrm{~cm}$ for Europid men and $\geq 80 \mathrm{~cm}$ for Europid women $)^{38}$. According to this new definition, the prevalences described above would be increased.

The metabolic syndrome is associated with an increased risk of both diabetes ${ }^{39}$ and cardiovascular disease $^{40,41}$. Abdominal obesity is a risk factor for cardiovascular disease worldwide ${ }^{42}$, and it is becoming a dramatic issue for national health systems ${ }^{43}$. Specifically, overweight and obesity in childhood are highly associated with multiple comorbidities, elevated blood pressure values, dyslipidaemia, reduced insulin sensitivity and alterations of large and minor vessels ${ }^{44,45}$. Obesity is often associated with insulin resistance and the components of metabolic syndrome. In fact, the degree of insulin resistance impacts the risk for obesity-related metabolic comorbidities, with a greater risk for type 2 diabetes and cardiovascular disease in patients who are severely insulin-resistant ${ }^{46}$.

Recently, we published the first study in Spain to report on the degree of blood pressure control achieved in hospital-based hypertension units across the whole nation in light of recommendations contained in international guidelines ${ }^{47}$. We performed a survey covering 4049 patients, aged 18 years or older, who had a diagnosis of essential hypertension, had been using antihypertensive 
therapy at least for 1 year, had been seen at 47 hospitalbased hypertension units nationwide and had been regularly followed up by the same medical team in each unit. Baseline data for the 4049 hypertensives studied are shown in Table 1. It should be highlighted the increased mean body mass index $29.5 \pm 5 \mathrm{~kg} \mathrm{~m}^{-2}$ and the high prevalence of overweight (42.3\%) and obesity (41.1\%) among hypertensive patients attended in hospital-based hypertension units $^{47}$. The univariate analysis showed that poorer blood pressure control occurred in older patients, females, obese patients, diabetic patients and in those treated with two or more antihypertensive drugs, and all variables, except for gender, remained statistically significant in the multivariate analysis ${ }^{47}$. Table 2 shows the percentages of systolic and diastolic blood pressure control according to body mass index, which is significantly lower among obese hypertensive patients. From the whole group, 63.7\% were using two or more antihypertensive drugs. ACE inhibitors, Ang II receptor antagonists and calcium channel blockers were

Table 1 Baseline demographic and clinical characteristics of the sample (from Ref. 47 with permission)

\begin{tabular}{|c|c|}
\hline Variable & \\
\hline $\begin{array}{l}\text { Age (years) } \pm \mathrm{SD} \\
\quad<60 \text { years, } n(\%)\end{array}$ & $\begin{array}{r}55.6 \pm 12 \\
2006(49.5)\end{array}$ \\
\hline \multicolumn{2}{|l|}{ Gender } \\
\hline Male, $n(\%)$ & $2001(49.4)$ \\
\hline Female, $n(\%)$ & $2048(50.6)$ \\
\hline Blood pressure $(\mathrm{mmHg}) \pm \mathrm{SD}$ & $144 \pm 20 / 85 \pm 10$ \\
\hline $\mathrm{BMI}\left(\mathrm{kg} \mathrm{m}^{-2}\right) \pm \mathrm{SD}$ & $29.5 \pm 5$ \\
\hline$<20(\%)$ & 0.8 \\
\hline $20-25(\%)$ & 15.8 \\
\hline $25-30(\%)$ & 42.3 \\
\hline$\geq 30(\%)$ & 41.1 \\
\hline \multicolumn{2}{|l|}{ Diabetes* (\%) } \\
\hline Type 1 & 1.5 \\
\hline Type 2 & 20.6 \\
\hline Renal failure* & 16.5 \\
\hline \multicolumn{2}{|l|}{ Proteinuria* $(\%)$} \\
\hline $30-300 \mathrm{mg} \mathrm{day}^{-1}$ & 29.4 \\
\hline $300-1000 \mathrm{mg} \mathrm{day}^{-1}$ & 8.3 \\
\hline$>1000 \mathrm{mg} \mathrm{day}^{-1}$ & 5.7 \\
\hline \multicolumn{2}{|l|}{ Other TOD/clinical CVD* (\%) } \\
\hline Left ventricular hypertrophy & 22.4 \\
\hline Angina/previous $\mathrm{M} 1$ & 8.5 \\
\hline Heart failure & 2.5 \\
\hline Stroke or transient ischaemic attack & 9.2 \\
\hline Retinopathy grades 3 and 4 & 2.7 \\
\hline \multicolumn{2}{|l|}{ Other risk factors* $(\%)$} \\
\hline Smoking & 15.1 \\
\hline Hypercholesterolaemia & 35.5 \\
\hline
\end{tabular}

SD - standard deviation; BMI - body mass index; TOD - target organ damage; CVD - cardiovascular disease; $\mathrm{Ml}$ - myocardial infarction. For definitions of clinical characteristics see Methods.

${ }^{*}$ The percentages listed are those for the population with the characteristic divided by the population in whom the condition was determined. the drugs most frequently prescribed. These data confirm that hypertensive patients followed up in hospital hypertension clinics exhibit an increased cardiovascular risk linked to a high prevalence of target organ damage, associated clinical conditions, diabetes or other major cardiovascular risk factors, with a great relevance of overweight and obesity.

\section{Clinical management of obesity-related hypertension}

Despite the fact that an increasing number of hypertensive patients now present with a body mass index in excess of $30 \mathrm{~kg} \mathrm{~m}^{-2}$, there are currently no specific recommendations or treatment algorithms for obesity hypertension ${ }^{48,49}$.

The lack of an established approach to the management of obesity hypertension is perhaps largely caused by the lack of data from prospective intervention studies on obese hypertensives ${ }^{50}$. Despite the fact that many recent intervention trials comparing different antihypertensive drugs have been reported, they have not been designed specifically for obese hypertensive patients. Although some patients participating in these trials may have been obese, general extrapolation of these data may not be justified ${ }^{5}$. Because obesity hypertension results in significant cardiovascular, neurohormonal, renal and metabolic changes, a comprehensive approach to treatment including both weight loss and pharmacological approaches would be warranted ${ }^{5}$. Antihypertensive drugs prescription should be based on guidelines recommendations for management of hypertension ${ }^{48,49}$, taking into account the growing evidences about the relationship between some antihypertensive drugs and the development of newonset diabetes. Compared to diuretics or 'conventional' (diuretic and/or beta blocker) therapy, blockers of the RAS, and to a lesser extent calcium antagonists, reduced the risk of new-onset diabetes substantially ${ }^{51}$. Physicians should take notice of the presence of several characteristics related to the development of diabetes (prediabetic state, metabolic syndrome, glucose intolerance, overweight-obesity) when they select long-term medications devoted to cardiovascular protection for hypertensive patients ${ }^{51}$.

Combination therapy for multiple cardiovascular risk factors is critical for the successful management of patients presenting obesity-related hypertension. Either ACE inhibitors or Ang II receptor blockers are preferable antihypertensive drugs as initial therapy of these patients,

Table 2 Systolic and diastolic blood pressure control according to BMI (from Ref. 47 with permission)

\begin{tabular}{lcccc}
\hline BMI & $n$ & SBP/DBP $<140 / 90 \mathrm{mmHg}(\%)$ & $\mathrm{SBP}<140 \mathrm{mmHg}(\%)$ & $\mathrm{DBP}<90 \mathrm{mmHg}(\%)$ \\
\hline$<30 \mathrm{~kg} \mathrm{~m}^{-2}$ & 2385 & 46 & 50 & 71 \\
$\geq 30 \mathrm{~kg} \mathrm{~m}^{-2}$ & 1664 & 34 & 39 & 63 \\
\hline
\end{tabular}

$\mathrm{BMI}$ - body mass index; SBP - systolic blood pressure; DBP - diastolic blood pressure. 
unless contraindications or compelling indications for other drugs. Considering that most patients will need more than one antihypertensive drug to achieve the blood pressure goal, a calcium-channel blocker, $\alpha$-blocker or thiazide diuretic could be considered for combined therapy ${ }^{52}$.

\section{Acknowledgements}

Conflict of interest declaration: The authors had no conflicts of interest to report.

Authorship contribution: J.S. wrote the manuscript and L.M.R. reviewed it.

\section{References}

1 Freedman DS, Khan LK, Serdula MK, Galuska DA, Dietz WH. Trends and correlates of class 3 obesity in the United States from 1990 through 2000. JAMA 2002; 288: 1758-61.

2 Thompson D, Edelsberg J, Colditz GA, Bird AP, Oster G. Lifetime health and economic consequences of obesity. Archives of Internal Medicine 1999; 159: 2177-83.

3 Meigs JB. Epidemiology of the insulin resistance syndrome. Current Diabetes Report 2003; 3: 73-9.

4 Haffner S, Taegtmeyer H. Epidemic obesity and the metabolic syndrome. Circulation 2003; 108: 1541-5.

5 Sharma AM. Is there a rationale for angiotensin blockade in the management of obesity hypertension?0. Hypertension 2004; 44: 12-19.

6 Hall JE. The kidney, hypertension and obesity. Hypertension 2003; 41(Part 2): 625-33.

7 Hall JE, Henegar JR, Shek EW, Brands MW. Role of renin-angiotensin system in obesity hypertension. Circulation 1997; 96: I-33.

8 Robles RG, Villa E, Santirso R, Martinez J, Ruilope LM, Cuesta C, et al. Effects of captopril on sympathetic activity, lipid and carbohydrate metabolism in a model of obesityinduced hypertension in dogs. American Journal of Hypertension 1993; 6: 1009-19.

9 Reisen E, Weir M, Falkner B, Hutchinson HG, Anzalone DA, Tuck ML. Lisinoprin versus hydrochlorothiazide in obese hypertensive patients. Hypertension 1997; 30: 140-5.

10 Engeli S, Sharma AM. Role of adipose tissue for cardiovascular-renal regulation in health and disease. Hormone and Metabolic Research 2000; 32: 485-99.

11 Ailhaud G, Fukamizu A, Massiera F, Negrel R, Saint-Marc P, Teboul M. Angiotensinogen, angiotensin II and adipose tissue development. International Journal of Obesity Related Metabolic Disorder 2000; 24: S33-5.

12 Rotimi C, Cooper R, Ogunbiyi O, Morrison L, Ladipo M, Tewksbury $\mathrm{D}$, et al. Hypertension, serum angiotensinogen, and molecular variants of the angiotensinogen gene among Nigerians. Circulation 1997; 95: 2348-50.

13 Pratt JH, Ambrosius WT, Tewksbury DA, Wagner MA, Zhou L, Hanna MP. Serum angiotensinogen concentration in relation to gonadal hormones, body size, and genotype in growing young people. Hypertension 1998; 32: 875-9.

14 Massiera F, Bloch-Faure M, Ceiler D, Murakami K, Fukamizu A, Gasc JM, et al. Adipose angiotensinogen is involved in adipose tissue growth and blood pressure regulation. FASEB Journal 2001; 15: 2727-9.

15 Furuhashi M, Ura N, Takizawa H, Yoshida D, Moniwa N, Murakami $\mathrm{H}$, et al. Blockade of the renin-angiotensin system decreases adipocyte size with improvement in insulin sensitivity. Journal of Hypertension 2004; 22: 1977-82.

16 Yvan-Charvet L, Even P, Bloch-Faure M, Guerre-Millo M, Moustaid-Moussa N, Ferre $\mathrm{P}$, et al. Deletion of the angiotensin type 2 receptor (AT2R) reduces adipocyte cell size and protects from diet induced obesity and insulin resistance. Diabetes 2005; 54: 991-9.

17 Ailhaud G. Cross talk between adipocytes and their precursors: relationships with adipose tissue development and blood pressure. Annals of New York of Academic Science 1999; 892: 127-33.

18 Cassis LA, English VL, Bharadwaj K, Boustany CM. Differential effects of local versus systemic angiotensin II in the regulation of leptin release from adipocytes. Endocrinology 2004; 145: 169-74.

19 Arita Y, Kihara S, Ouchi N, Takahashi M, Maeda K, Miyagawa $\mathrm{J}$, et al. Paradoxical decrease of an adiposespecific protein, adiponectin, in obesity. Biochemical and Biophysical Research Communication 1999; 257: 79-83.

20 Okamoto Y, Kihara S, Ouchi N, Nishida M, Arita Y, Kumada $\mathrm{M}$, et al. Adiponectin reduces atherosclerosis in apolipoprotein E-deficient mice. Circulation 2002; 106: 2767-70.

21 Furuhashi M, Ura N, Higashiura K, Murakami H, Tanaka M, Moniwa $\mathrm{N}$, et al. Blockade of the renin-angiotensin system increases adiponectin concentrations in patients with essential hypertension. Hypertension 2003; 42: 76-81.

22 Engeli S, Böhnke J, Gorzelniak K, Janke J, Schling P, Bader $\mathrm{M}$, et al. Weight loss and the renin-angiotensin-aldosterone system. Hypertension 2005; 45: 356-62.

23 Rahmouni K, Correia MLG, Haynes WG, Mark AL. Obesityassociated hypertension. New insights into mechanisms. Hypertension 2005; 45: 9-14.

24 Goodfriend TL, Calhoun DA. Resistant hypertension, obesity, sleep apnea, and aldosterone: theory and therapy. Hypertension 2004; 43: 518-24.

25 Ehrhart-Bornstein M, Lamounier-Zepter V, Schraven A, Langenbach J, Willenberg HS, Barthel A, et al. Human adipocytes secrete mineralocorticoid-releasing factors. Proceedings of the National Academic Science USA 2003; 100: 14211-16.

26 Goodfriend TL, Ball DL, Egan BM, Campbell WB, Nithipatikom K. Epoxy-keto derivative of linoleic acid stimulates aldosterone secretion. Hypertension 2004; 43: 358-63.

27 de Paula RB, da Silva AA, Hall JE. Aldosterone antagonism attenuates obesity-induced hypertension and glomerular hyperfiltration. Hypertension 2004; 43: 41-7.

28 Reaven G. Metabolic syndrome: pathophysiology and implications for management of cardiovascular disease. Circulation 2002; 106: 286-8.

29 Executive Summary of the Third Report of the National Cholesterol Education Program (NCEP). Expert Panel on Detection, Evaluation, And Treatment of High Blood Cholesterol In Adults (Adult Treatment Panel III). JAMA 2001; 285: 2486-97.

30 Cuspidi C, Meani S, Fusi V, Severgnini B, Valerio C, Catini E, et al. Metabolic syndrome and target organ damage in untreated essential hypertensives. Journal of Hypertension 2004; 22: 1991-8.

31 Chen J, Muntner P, Hamm LL, Jones DW, Batuman V, Fonseca V, et al. The metabolic syndrome and chronic kidney disease in US adults. Annals of Internal Medicine 2004; 140: 167-74.

32 Safar ME, Thomas F, Blacher J, Nzietchueng R, Bureau JM, Pannier $\mathrm{B}$, et al. Metabolic syndrome and age-related progression of aortic stiffness. Journal of Amercian College of Cardiology 2006; 47: 72-5.

33 Ford ES, Giles WH, Dietz WH. Prevalence of the metabolic syndrome among US adults: findings from the third National 
Health and Nutrition Examination Survey. JAMA 2002; 287: 356-9.

34 Ford ES, Giles WH, Mokdad AH. Increasing prevalence of the metabolic syndrome among US Adults. Diabetes Care 2004; 27: 2444-9.

35 Banegas JR, Ruilope LM. Epidemic of metabolic diseases. A warning call. Medicina Clinica (Barcelona) 2003; 120 99-100.

36 Segura J, Campo C, Roldan C, Christiansen H, Vigil L, García-Robles R, et al. Hypertensive renal damage in metabolic syndrome is associated with glucose metabolism disturbances. Journal of American Society of Nephrology 2004; 15(Suppl. 1): S37-42.

37 Bruno G, Merletti F, Biggeri A, Bargero G, Ferrero S, Runzo $\mathrm{C}$, et al. Metabolic syndrome as a predictor of all-cause and cardiovascular mortality in type 2 diabetes: the Casale Monferrato Study. Diabetes Care 2004; 27: 2689-94.

38 Alberti KG, Zimmet P, Shaw J, for the IDF Epidemiology Task Force Consensus Group. The metabolic syndrome - a new worldwide definition. Lancet 2005; 366: 1059-62.

39 Grundy SM, Hansen B, Smith Jr SC, Cleeman JI, Kahn RA, American Heart Association; National Heart, Lung, and Blood Institute; American Diabetes Association. Clinical management of metabolic syndrome: report of the American Heart Association/National Heart, Lung, and Blood Institute/American Diabetes Association conference on scientific issues related to management. Circulation 2004; 109: 551-6.

40 Isomaa B, Almgren P, Tuomi T, Forsen B, Lahti K, Nissen M, et al. Cardiovascular morbidity and mortality associated with the metabolic syndrome. Diabetes Care 2001; 24: 683-9.

41 Lakka HM, Laaksonen DE, Lakka TA, Niskanen LK, Kumpusalo E, Tuomilehto J, et al. The metabolic syndrome and total and cardiovascular disease mortality in middleaged men. Journal of American Medical Association 2002; 288: 2709-16.

42 Yusuf S, Hawken S, Ounpuu S, Dans T, Avezum A, Lanas F, et al.; INTERHEART Study Investigators. Effect of potentially modifiable risk factors associated with myocardial infarction in 52 countries (the INTERHEART study): case-control study. Lancet 2004; 364: 937-52.

43 Porier P, Giles TD, Bray GA, Hong Y, Stern JS, Pi-Sunyer FX, et al. Obesity and cardiovascular disease. Pathophysiology, evaluation and effect of weight loss. Arteriosclerosis Thrombosis and Vascular Biology 2006; 26: 968-76.

44 Schiel R, Beltschikow W, Kramer G, Stein G. Overweight, obesity and elevated blood pressure in children and adolescents. European Journal of Medical Research 2006; 11: 97-101.

45 Srinivasan SR, Myers L, Berenson GS. Changes in metabolic syndrome variables since childhood in prehypertensive and hypertensive subjects. The Bogalusa Heart Study. Hypertension 2006; 48: 33-9.

46 Bacha F, Saad R, Gungor N, Arslanian SA. Are obesityrelated metabolic risk factors modulated by the degree of insulin resistance in adolescents. Diabetes Care 2006; 29: 1599-604.

47 Banegas JR, Segura J, Ruilope LM, Luque M, García-Robles $\mathrm{R}$, Campo C, et al:; on behalf of the CLUE Study Group Investigators. Blood pressure control and physician management of hypertension in hospital hypertension units in Spain. Hypertension 2004; 43: 1338-44.

48 Chobanian AV, Bakris GL, Black HR, Cushman WC, Green LA, Izzo Jr JL, et al:; National Heart, Lung, and Blood Institute Joint National Committee on Prevention, Detection, Evaluation, and Treatment of High Blood Pressure; National High Blood Pressure Education Program Coordinating Committee. The Seventh Report of the Joint National Committee on Prevention, Detection, Evaluation, and Treatment of High Blood Pressure: The JNC 7 Report. JAMA 2003; 289: 2560-71.

49 Guidelines Committee. 2003 European Society of Hypertension - European Society of Cardiology guidelines for the management of arterial hypertension. Journal of Hypertension 2003; 21: 1011-53.

50 Sharma AM, Pischon T, Engeli S, Scholze J. Choice of drug treatment for obesity-related hypertension: where is the evidence? Journal of Hypertension 2001; 19: 667-74.

51 Segura J, Campo C, Ruilope LM, Rodicio JL. Do we need to target 'prediabetic' hypertensive patients? Journal of Hypertension 2005; 23: 2119-25.

52 Segura J, Ruilope LM. Antihypertensive therapy in patients with metabolic syndrome. Current Opinion in Nephrology and Hypertension 2006; 15: 493-7. 